\title{
Telecoupling of the Trade of Donkey-Hides between Botswana and China: Challenges and Opportunities
}

\author{
Dimpho Malebogo Matlhola ${ }^{1,2}$ and Ruishan Chen $1, * \mathbb{C}$ \\ 1 Key Laboratory of Geographic Information Science (Ministry of Education), School of Geographical Sciences, \\ Institute of Eco-Chongming (IEC), East China Normal University, 500 Dongchuan Road, Shanghai 200241, \\ China; md.matlhola@gmail.com \\ 2 Okavango Research Institute, University of Botswana, P/Bag 285 Maun, Botswana \\ * Correspondence: rschen@geo.ecnu.edu.cn
}

Received: 13 December 2019; Accepted: 20 February 2020; Published: 26 February 2020

\begin{abstract}
International trade has become a major threat to biodiversity in the telecoupled world. The literature on biodiversity loss mostly concentrates on wild species; however, the increasing loss of and demand for domesticated species are overlooked. Donkeys are decreasing in many countries because of economic development, urbanization, and increased demand for donkey hides in China. The donkey population in Africa has rapidly declined recently due to supplying China with donkey hides for the production of highly demanded and legalized traditional medicine, ejiao. As a result, some African countries, including Botswana, banned the export of donkey hides. Animal protection and media continuously reported threats over the extinction of donkeys and exacerbated rural livelihood in developing countries, however, limited literature has investigated the causes and effects of donkey-hide trade and its policy interventions. This paper applies the telecoupling framework and uses the data extracted from the media reports and FAO, to understand the scale and impacts of donkey-hide trade from Botswana to China. We also explore the challenges and opportunities of donkey-hide trade for Botswana, highlighting the mechanisms need to be established to regulate the donkey-hide trade, and also to harness available opportunities if the trade ban is lifted in the future.
\end{abstract}

Keywords: donkey hides; trade; China; opportunities; telecoupling

\section{Introduction}

Africa's rich and diverse ecosystems generate goods and services that are essential to provide food, water, energy, health, and livelihood needs for the continent [1]. However, sustainable use of ecosystem services and biodiversity have been challenged by the growing population, urbanization, changing consumer behavior, and rising volume of internal and international trade. Africa shared about $4 \%$ of worldwide animal production in 2012 and has generally been seen as self-sufficient in animal protein [2]. Most African countries have mainly invested in cattle production and traded with European countries.

The literature on the trading of biodiversity has largely focused on wild species. Very little attention has been paid to the increasing consumption of livestock and its impacts on their sustainability. Recently, the demand for donkey hides in China has increased resulting in donkey population decline globally [3,4]. The global population of donkeys is estimated to be $40-46$ million donkeys [3]. Donkeys in developing countries are valued as working animals. However, the roles and economic values of donkeys have changed greatly over the years. The demand for donkey hides in China has triggered a global trade of donkeys. The donkey hides are used to produce one type of traditional medicine, ejiao. A British-based charity, The Donkey Sanctuary, has estimated that China's demand for donkeys is about 10 million annually. Many countries in Africa export donkey hides to China. Sub-Saharan Africa 
exports about 1.8 million donkey hides to China annually [4]. For individual countries, South Africa has a legal annual export quota of 10,500 donkey hides to Hong Kong and mainland China, but the real quantity is higher, as smuggled donkey hides are frequently reported [5]. In Nigeria, donkey-hide trade has been seen as a lucrative business with the potential for making quick cash, with 3000 donkeys sold per week by dealers [6]. In Kenya, a \$6 million USD Chinese-operated slaughterhouse in Baringo has been slaughtering hundreds of donkeys a day [6].

The Chinese demand for donkey hides has also boosted donkey-hide trade in Botswana; however, the multi-billion-dollar trade was short-lived. The Government of Botswana restricted the export of donkey hides 2017 [7], as some irregularities by donkey slaughterhouses were reported by local communities and media [8,9]. Theft and smuggling of donkeys and/or their hides has persisted in Botswana, despite the restriction imposed on trade [8]. This resulted in inadequate information on the trade volume of donkey hides. Currently, the majority of available information is from media reports. Furthermore, the socio-economic values of donkeys are not fully explored. The ban on donkey-hides export in Botswana was introduced with no survey conducted on the donkey population nor an assessment on the impacts of trade on the livelihoods of farmers.

Although the importance of telecoupling perspectives on international trade is increasingly recognized, there has not yet been an assessment of the causes and effects of international donkey-hide trade, which greatly hinders our understanding of the socioeconomic and environmental trade-offs and synergies across the importing and exporting countries. This study, therefore, reviewed donkey-hide trade from Botswana to China and the causes of restrictions imposed on trade and assessed challenges and opportunities for the sector using the telecoupling framework. Information on Botswana-China donkey-hide trade was extracted from reports, news articles, literature and FAO dataset from 2010 to 2019, examining the rise and fall of donkey-hide trade from Botswana to China, and identifying its impact and potential opportunities. The paper first looked at the roles of donkeys in Botswana, then explained the trade of donkey hides and its ban in Botswana, concluding with an assessment of challenges and opportunities of donkey-hide trade from Botswana to China.

\section{Methods and Materials}

\subsection{Telecoupling Framework on Donkey-Hide Trade}

Telecoupling refers to socioeconomic and environmental interactions between distant human-natural systems, and these interactions have become more extensive and intensive in the interconnected world [10]. The telecoupling framework highlights the importance of socioeconomic and environmental interactions over large distances for understanding contemporary sustainability challenges $[10,11]$. The framework has been used to examine the flow of information, energy, materials, people, organisms, goods and services around the world [12]. Trade is a typical flow in telecoupled systems because both the production activities in an exporting country and the consumption activities in an importing country have socioeconomic and environmental effects at different scales. Through international trade, countries are motivated to provide products to meet the other country's demands, thus increasing their foreign exchange reserves and economic freedom to buy goods and services from other countries; and this process can change the socioeconomic and environmental conditions at both sides of the trade [13].

Here, we adapted the telecoupling framework to examine the donkey-hide trade from Botswana to China (Figure 1), by understanding the rising demand of donkey hides in China, increasing export of donkey hides, the impacts on human-natural systems in Botswana, the policy responses to the negative impacts, and also the challenges and opportunities of the donkey-hide trade from Botswana to China. 


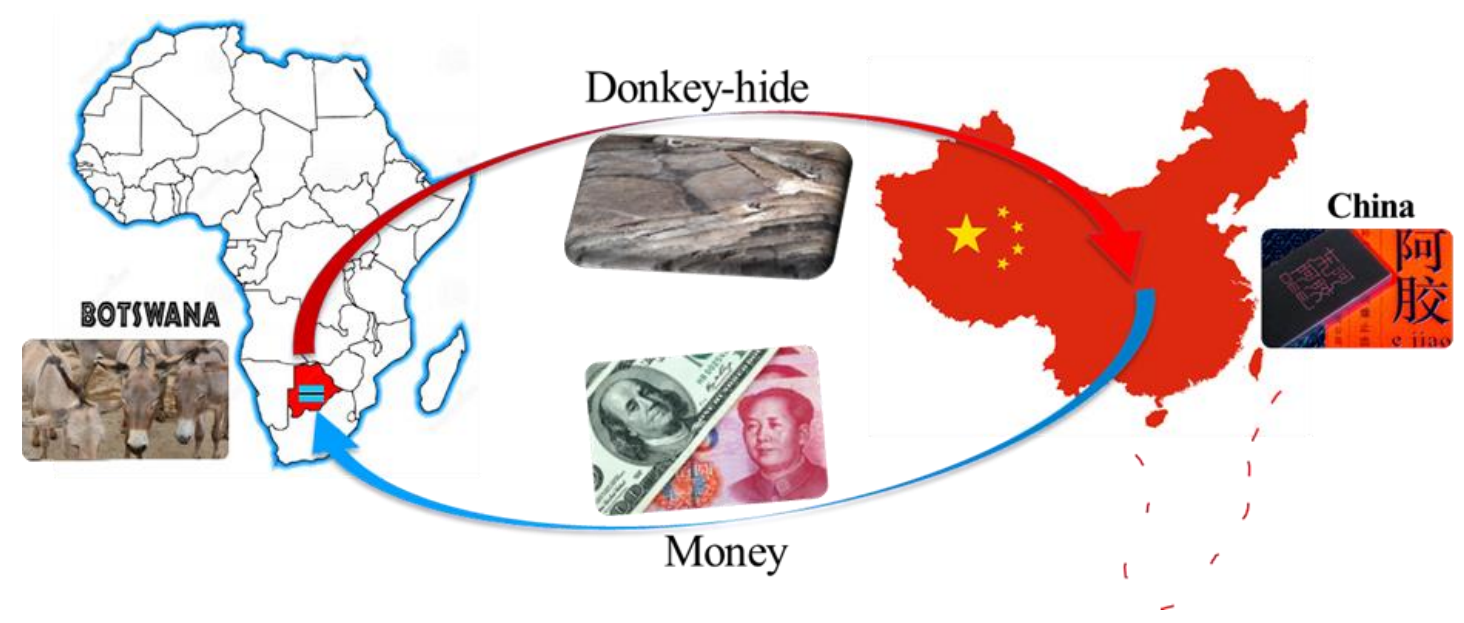

Figure 1. Telecoupling of donkey-hide trade from Botswana to China.

\subsection{Data and Methods}

The increasing interest of organizations and media over the topic of donkey-hide trade necessitated the fusion-interpretative and post-positivist paradigms in this study. Literature and document analysis were used to assess the pattern and impacts of trade of donkey hides, its challenges, and opportunities for Botswana. Databases include Google Scholar, EBSCO Discovery Service, as well as search engines like Google and Baidu, which were searched using keywords such as donkey; donkey skin; donkey hides; Botswana; trade; donkey demand; China; etc. However, there was a challenge in finding scholarly articles relating to the donkey-hide trade, several articles reviewed were news reports and newsletters from various organizations such as the Donkey Sanctuary. They were nonetheless used to establish the extent and impacts of donkey-hide trade from Botswana to China. Statistical data from the UN Food and Agriculture Organization (FAO) was used to show the changes in the donkey population in Botswana.

\section{Donkeys in Botswana}

\subsection{The Roles of Donkeys in Botswana}

Donkeys play a fundamental role in providing livelihoods for rural communities in Botswana [14]. The donkeys' roles vary socially, culturally, and economically depending on their geographical location [15]. They are important for the survival and sustainability of communities with no alternative resources, and areas not reachable by fuel-dependent vehicles [16]. Smallholder farming households, pastoralists, and microentrepreneurs in the transport sector mainly own donkeys as they cannot afford to have cattle or buy tractors [16]. The Government of Botswana purchased donkeys for poor farmers, through a government-assisted programmed called the Arable Land Development Programme (ALDEP), to plough their fields and grow crops [17]. Donkeys were mainly used to do work such as tilling of the soil; drawing carts; transporting people, goods, or crops to markets; etc. [16-25].

Using donkeys to plough land is seen as a sustainable way of land management compared to heavy machinery. Donkeys provide manure for crops in both rural and urban areas [21]. Due to their small bodies with a relatively low requirement of water and food, donkeys are preferred by local communities in arid and semi-arid areas over other animals [20,21]. During periods of drought when large fluctuations in cattle populations are observed, people resort to donkeys because they have the advantage of surviving in drought compared to cattle [17].

The roles of donkeys are changing as their economic and social values are recognized. Donkey meat is consumed by communities historically in Botswana [4]. Donkey milk is believed to have medicinal effects and is given to children to prevent diseases. For instance, Maasai women in Kenya give donkey milk to their children when they have pneumonia or a severe cough. Donkey milk is also 
used as an ingredient in beauty products both in Botswana and South Africa. However, there is scarce data and reports on the socio-economic roles of donkeys in Botswana.

\subsection{Donkey Population and Dynamics}

Botswana is a beef country, exporting much of its beef to the European Union. As the demand for donkey hides in China increased, Botswana discovered a niche in the donkey market in 2016, and allowed export of live donkeys, their meat, and hides to China. However, the available statistics of the donkey population and donkey hides are unreliable. The discrepancy in the statistics of slaughtered donkeys is largely associated with illegal export and smuggling of donkey hides. The Government of Botswana estimated that the country had a population of 366,000 donkeys in 2008 [26]. Data from FAO shows that the donkey population in Botswana has increased from 1971 to 2009, then declined to a record low in 2015 to nearly half of the population in 2009 (Figure 2) [3]. The donkey population has declined by 37\% between 2011 and 2017 [27].

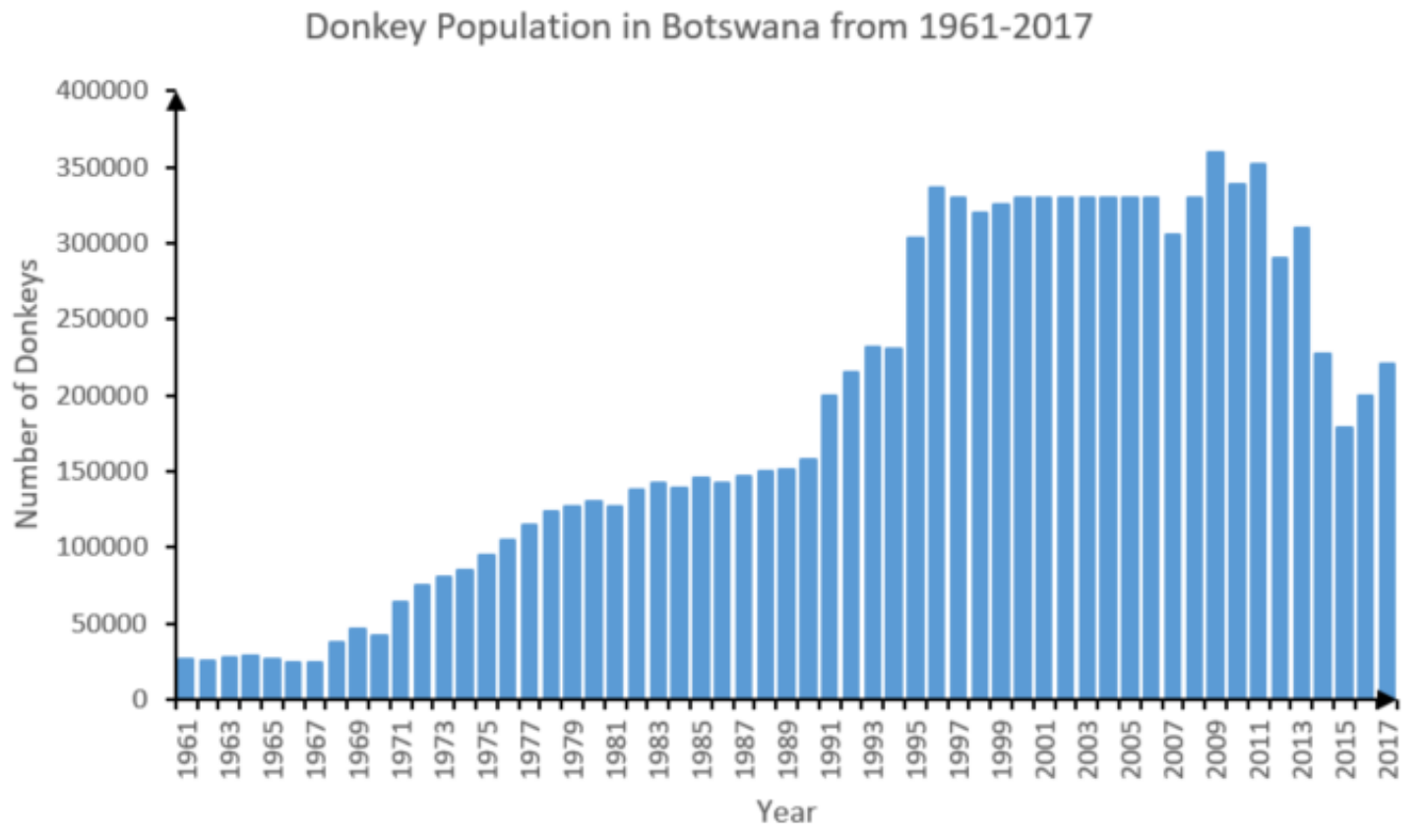

Figure 2. Population dynamics of donkeys in Botswana from 1961 to 2017 (Source: FAO).

\section{Trade of Donkey Hides from Botswana to China}

\subsection{Demand for Donkey and Donkey Hides in China}

China's increasing demand for donkey hides has been triggered mainly by the increased demand for ejiao, a traditional Chinese medicine that is widely preferred for health care. Some of the uses of ejiao include as an ingredient for lifestyle products [28], for the medicinal purposes used to improve blood circulation and cure blood diseases such as anemia and low blood cell counts [29], menopausal syndrome, and gastric cancer [30,31].

China had the largest donkey population in the world in 1990 and has since declined from 11 million in 1990 to four million in the last 20 years [15]. The rapid urbanization and industrialization have caused the decline of the donkey population in China. However, the increasing affluence of expanding the middle-class and aging population has promoted the consumption of ejiao. The reduction of the population has placed a very high price on donkeys and especially their hides. It is likely that the demand and production of ejiao will continue to increase in the next few years because of the increasing wealth of the population and the awareness of health care. 
From 2013 to 2016, the annual production of ejiao has increased from 3200 tonnes to 5600 tonnes, an annual growth of more than $20 \%$ [27]. It is estimated that about 4 million donkey hides are needed annually to produce 5000 tonnes of ejiao; that is, one donkey hide can produce $1.25 \mathrm{~kg}$ of ejiao [32]. On the other hand, 10 million donkeys are slaughtered annually for the production of ejiao and nutritious meals [28]. Only approximately 1.8 million hides are sourced domestically for the production of ejiao in China. In 2016, approximately $25 \%$ of donkey hides were traded to China from Sub-Saharan Africa compared to just $2.3 \%$ in 1985 [15]. As the demand for ejiao increases, so does the demand for donkey hides.

\subsection{Trade of Donkey Hides and Its Ban from Botswana to China}

Great value has been established on donkeys and their products across the world in recent years [16]. Since the outburst of donkey hide trade in 2016 in Botswana, both Chinese-operated slaughterhouses and small-scale bush killings have been reported [8,9,33]. Ministry of Agricultural Development and Food Security (MoA) issued four donkey slaughter licenses to Chinese-operated slaughterhouses to operate in Francistown, Ghanzi, Lentsweletau, and Lobatse. Y2K Trading in Ghanzi and Mai Di in Lobatse were licensed to export donkey meat and hides, while Bo Chang (Pty) Limited in Francistown and the Development Advance Institute in Lentsweletau were licensed only to sell donkey meat locally [8,9]. Bo Chang (Pty) Limited set up its business in 2016, and by May 2017, it had exported at least 1000 donkey hides [8]. Markets have also sprung for middlemen, who selling donkeys at a higher price to Chinese-operated slaughterhouses [34]. Middlemen pay BWP150 (\$13.87 USD) per donkey and sell at BWP550 (\$50.84 USD) to slaughterhouses [8].

The donkey-hide trade in Botswana was short-lived due to some irregularities reported by media resulting in the ban of a trade by the Government of Botswana [7,8]. Approximately 500 starved and emaciated donkeys were found, and hundreds of rotten carcasses were dumped in makeshifts pits near Bo Chang slaughterhouse in Francistown in June 2017, with fluids seeping into the Tati River $[8,33]$. Several organizations (including the Donkey Sanctuary and the Society for the Protection of Animals Abroad) raised concerns about the rate of donkey slaughtering in Africa and the mistreatment of donkeys [34]. Rural communities also complained about the treatment of donkeys and the disposal of their waste. They noted that carcasses are been thrown into nearby bushes, leaving a bad smell and dirty water from slaughterhouses contaminate the air and streams of water in localities [8]. The Ministry of Agricultural Development and Food Security of Botswana announced the suspension of donkey slaughtering in 2017: "The public and slaughterhouses are informed that the slaughter of donkeys is suspended with immediate effect until further notice. All slaughterhouses issued to the operators are therefore withdrawn with immediate effect" [7]. Botswana joined other African countries like Uganda, Tanzania, Niger, Ghana, Gambia, Ethiopia, Burkina Faso, Mali, and Senegal to ban the export of donkey hides to China [4,7,35-37].

However, the donkey-hide trade and its ban led to a boom in the theft and illegal trade of donkeys [9,36-38]. One activist noted that "The ban has not stopped the donkey products trade. It has simply gone underground and donkeys are now being slaughtered in the bush" [8]. In Tanzania, residents were shocked to discover their donkeys being slaughtered, skinned, and left in the bush by unknown culprits [25]. The donkey hides are then smuggled to Kenya, South Africa, Zimbabwe, and Mozambique from countries that had banned the trade [8]. In Botswana, police officials have arrested what they called a "syndicate" of four Zimbabweans and a Chinese person for illegally slaughtering and exporting 1200 donkey hides to Zimbabwe, and the police also found over 900 donkey hides at the house of a citizen authorized to export cattle hides only [8].

\subsection{Impacts of Donkey Hide Trade in Botswana}

Over the past few years, donkeys have gained interest over their economic value because of the growing demand for hides, meat, and milk. The trade of donkey hides has affected the rural development of Botswana. Through the opening of slaughterhouses, locals have had employment 
opportunities as slaughterers and packagers of donkey hides. The price of the donkey has more than doubled since the inception of trade $[25,28]$. This makes it hard for poor people to afford buying donkeys to sustain their livelihoods [27]. In Kenya, the price of donkey hides was estimated at $\$ 130$ USD per donkey hide in 2017 [27]. Moreover, the middle man benefits more than the farmer. The middleman who has access to China can make more than BWP1,000 (\$92.12 USD), while the farmer makes as little as BWP150 (\$13.82 USD) [9].

Donkey-hide trade has affected the welfare and the livelihoods of local communities who rely on donkeys. Farmers are at risk of losing their independence when selling their source of draught power and transportation. The selling of donkeys by subsistence farmers may seem lucrative in the short term, but the long-term consequences of selling donkeys for quick cash are beyond their control. Agriculture in rural areas is also affected by the selling of donkeys in excess numbers. The remaining donkeys in some villages are insufficient to work for the farmers, which therefore affects food production and local livelihood.

According to the pollution heaven hypothesis, more developed countries can avoid negative environmental impacts of production by setting up industries in less developed countries and receive processed products [39]. China has built slaughterhouses in Botswana to slaughter donkeys in order to avoid handling waste and by-products of donkeys. It is claimed that waste from slaughterhouses are thrown into water streams and bushes, causing air and water pollution in Botswana. However, it is not clear whether China, as the importing country is affected by the waste from slaughterhouses. Environmental impacts of donkey-hide trade in China can be assessed further in future papers. China's imports of other products (e.g., forest products) have been identified as a driving force behind forest loss and degradation in exporting countries of the Asia-Pacific region [40,41]. This proves that China can have less environmental impacts when trading with Botswana.

Moreover, the rates at which donkeys are slaughtered cause a threat to the extinction of donkeys in Botswana. In Boteti, farmers revealed that 128 donkeys were slaughtered in just two weeks. Since 2016, Botswana has lost more than $50 \%$ of its donkey population [37]. It is estimated that the slaughterhouse at the Development Advance Institute in Lentsweletau alone slaughters 80 donkeys a day; at this rate, about 158,400 donkeys will be slaughtered in just one year-more than half of the estimated total nationwide population. This rate will endanger the donkey population in Botswana.

Despite the trade ban, donkey-hide trade is still ongoing illegally; donkeys are stolen from farmers who are not willing to sell. Donkey hides are then smuggled from Botswana through Zimbabwe, South Africa, and Mozambique, or from Tanzania via Kenya to China. The theft and smuggling of donkeys have negatively affected the socio-economic status of communities, poor farmers have become poorer.

\section{Opportunities and Challenges of Donkey-Hide Trade}

\subsection{Challenges of Donkey-Hide Trade for Botswana}

Despite the ban on the donkey-hide trade in Botswana, the sector is still facing many challenges. The Ministry of Agricultural Development and Food Security has not conducted any surveys or analyses on the donkey sector. Prior to the banning of donkey-hide trade, the government had no regulation or policy regulating the trade and movement of donkey hides. It is estimated that 1.9 million donkeys are required to produce 5000 tonnes of ejiao to meet China's demand, and no single country can sustainably supply this number of donkeys. Poor management of waste and excessive slaughtering of donkeys are affecting the local community and threatened the existence of donkeys.

Lack of regulations on donkey-hide trade makes it hard for the Government of Botswana to have proper recordings and accurate statistics of donkey population dynamics. The cost and benefit of the sector cannot be determined accurately if the available information is inaccurate. Furthermore, the lack of punishment for stealing and smuggling has resulted in the farmers losing their working animals and sources of income. 


\subsection{Opportunities of Donkey-Hide Trade for Botswana}

Opportunities of donkey-hide trade include investing in the breeding of donkeys to export the hides. Dong'e Ejiao Corporation Limited (DEEJ), the biggest producer of ejiao in China, claims it can breed donkeys double the size of an ordinary donkey as a way of reducing the number of hides required for ejiao production and also reducing import from other countries. Other technological and knowledge transfer may include ejiao production, which will create employment opportunities for locals and improve their livelihoods. The transfer of the skills to manufacture ejiao in Botswana can benefit both Botswana and China and also enlarge the ejiao market in Africa and China's other One Belt One Road partners. China can also invest in Botswana financially.

Another opportunity may exist for better use of the by-products of donkeys and improve resource efficiency. Botswana can carry out studies and establish industries to use donkey by-products like carcasses. People in Europe, China, Tunisia, Morocco, and beyond eat donkey meat, and this is a market opportunity for Botswana to sell donkey meat. The by-products can also be used as manure for crop production or animal feeds with effective management. Improved research will inform policy and management interventions for addressing both the threats and opportunities of donkey-hide trade. Botswana can take advantage of the opportunities under the Belt and Road Initiative to promote donkey-hide production and trade.

\section{Conclusions}

The telecoupling framework is a tool used to investigate interactions between distant human-natural systems, it can help to identify knowledge gaps for sustainable management of trade in both importing and exporting countries. We focus on international trade, a major channel of telecoupling flows, and in particular on the international trade of donkey hides. The demand for donkey hides in China is the main driver for the slaughtering of donkeys in Botswana. This demand has caused significant effects on donkey population and rural livelihood in Botswana and beyond. The economic value of donkeys increased as their hides are the main ingredient in the production of traditional medicine, ejiao in China. Rapid urbanization and industrialization in China have resulted in a sharp decline of donkey populations within the country; however, the improved economic situations and increasing the aging population have raised the consumption of ejiao. This causes China to search for donkeys worldwide, especially in Africa, where there are plenty of donkeys at a low price. As a result, the donkey population in Botswana declined by over $50 \%$ from 2009 , threatening their existence. The current shortfall in the supply of donkeys in Botswana and other countries cannot meet the the Chinese demand for donkey hides. Botswana then banned donkey-hide export to China in 2017. However, the ban stimulated illegal trade and smuggling of donkey hides in Botswana; threatening the livelihoods of local communities. Small farmers in Botswana feel more pressure from the donkey-hide trade as they may lose their source of livelihoods, draught power and transportation. And they cannot afford to buy donkeys once they lose one because of the increasing prices. The locals also face water and air pollution from the mismanagement of donkey-hide by-products. However, donkey-hide markets also created employment opportunities. As the economic viability of donkey production declines due to over slaughtering, donkeys could be bred by transferring the knowledge from China to create a more sustainable supply chain. Local communities and investors have opportunities to invest in the use of the by-products of donkeys rather than letting them pollute the environment.

The telecoupling framework provides a methodology for simultaneously exploring socioeconomic and environmental interactions in both sending and receiving countries and assessing the integrated outcomes of donkey-hide trade locally, regionally, and globally. The framework also helped to identify the drivers of donkey-hide trade and develop management options and policy interventions to regulate donkey-hide trade in Botswana if the ban is to be lifted in the future. Thus, promoting sustainable supply chain in the case of the global donkey-hide trade. The adoption of sustainable practices in the donkey-hide trade can create opportunities for all stakeholders in Botswana and China. Botswana thus needs to learn to navigate in this evolving telecoupled system to seize the available opportunities 
and contribute to solving the conservation challenges of the donkey population and improvement of rural development and livelihoods.

Author Contributions: Conceptualization, D.M.M. and R.C.; methodology, D.M.M. and R.C.; software, D.M.M. and R.C.; validation, D.M.M. and R.C.; investigation, D.M.M. and R.C.; resources, D.M.M. and R.C.; data curation, D.M.M. and R.C.; writing — original draft preparation, D.M.M. and R.C.; writing — review and editing visualization, D.M.M.; supervision, R.C.; project administration, D.M.M. and R.C.; funding acquisition, R.C. All authors have read and agreed to the published version of the manuscript.

Funding: This study was funded by the National Key R\&D Program of China (2017YFC1503001), the National Natural Science Foundation of China (41771119), and the Research Fund of ECNU One Belt One Road and global development institute (ECNU-BRGD-201802), and the support from the Institute of Eco-Chongming (IEC), East China Normal University.

Acknowledgments: The authors thank anonymous reviewers for their valuable feed-back. The authors also want to thank Janneke Merkx from The Donkey Sanctuary for supporting materials used in this paper.

Conflicts of Interest: The authors declare no conflict of interest.

\section{References}

1. IPBES. Summary for Policymakers of the Regional Assessment Report on Biodiversity and Ecosystem Services for Africa of the Intergovernmental Science-Policy Platform on Biodiversity and Ecosystem Services; Archer, E., Dziba, L.E., Mulongoy, K.J., Maoela, M.A., Walters, M., Biggs, R., Cormier-Salem, M., DeClerck, F., Diaw, M.C., et al., Eds.; IPBES Secretariat: Bonn, Germany, 2018.

2. Mankor, A. Promoting intra-Africa trade in animals and animal products. In Proceedings of the 20th Conference of the OIE Regional Commission for Africa, Lomé, Togo, 18-22 February 2013.

3. Food and Agriculture Organization. 2016. Available online: http://www.fao.org/faostat/en/\#home (accessed on 12 November 2019).

4. Donkeys for Africa. Taking a Stance against the Skin Trade. July 2017. Available online: www. donkeysforafrica.org (accessed on 10 September 2018).

5. Nkala, O. Border Band Its Turn to Donkey Smuggling. Oxpeckers. October 2017. Available online: https://oxpeckers.org/2017/10/border-bandits-turn-donkey-smuggling/ (accessed on 12 November 2019).

6. Donkeys for Africa. Feedback: Status of the Skin Trade. June 2018. Available online: www.donkeysforafrica. org/dfa_june18_flipfile/mobile/index.html\#p=2 (accessed on 10 September 2018).

7. News24. Botswana Bans Export of Donkey Products. News24. 29 June 2017. Available online: https://www.news24.com/Green/News/botswana-bans-export-of-donkey-products-20170629 (accessed on 12 November 2019).

8. Nkala, O. Inside Botswana's Illegal Donkey Trade. Oxpeckers. August 2017. Available online: https: //oxpeckers.org/2017/08/botswana-donkey-trade/ (accessed on 31 July 2018).

9. Mguni, M. Donkey Population Drops to 35-Year Low. Mmegi Newspaper. 15 February 2019. Available online: https://www.mmegi.bw/index.php?aid=79607\&dir=2019/february/15 (accessed on 12 April 2019).

10. Liu, J.; Hull, V.; Batistella, M.; DeFries, R.; Dietz, T.; Fu, F.; Zhu, C. Framing sustainability in a telecoupled world. Ecol. Soc. 2013, 18, 26. [CrossRef]

11. Liu, J.; Hull, V.; Luo, J.; Yang, W.; Liu, W.; Viña, A.; Zhang, J. Multiple telecouplings and their complex interrelationships. Ecol. Soc. 2015, 20. [CrossRef]

12. Hull, V.; Liu, J. Telecoupling: A new frontier for global sustainability. Ecol. Soc. 2018, 23, 41. [CrossRef]

13. Xiong, H.; Millington, J.D.; Xu, W. Trade in the telecoupling framework: Evidence from the metals industry. Ecol. Soc. 2018, 23, 11. [CrossRef]

14. Mrema, M. An economic analysis of the utilisation of donkeys in Botswana: The past and the future. In Donkeys, People and Development. A Resource Book of the Animal Traction Network for Eastern and Southern Africa (ATNESA); Starkey, P., Fielding, D., Eds.; ACP-EU Technical Centre for Agricultural and Rural Cooperation (CTA): Wageningen, The Netherlands, 2004; 164p. Available online: http://www.atnesa.orgAvailable online: http://www.atnesa.org/donkeys/donkeys-mrema-analysis-BW.pdf (accessed on 10 September 2018).

15. The Donkey Sanctuary. Under the Skin: The Emerging Trade in Donkey Skins and Its Implications for Donkey Welfare and Livelihoods. 2017. Available online: https://www.thedonkeysanctuary.org.uk/sites/uk/ files/2017-11/under_the_skin_report.pdf (accessed on 4 September 2018). 
16. Fernando, P.; Starkey, P. Donkeys and development: Socio-economic issues in the use and management of donkeys. In Proceedings of the Animal Traction Network of Eastern and Southern Africa (ATNESA) Workshop Improving Donkey Utilisation and Management, Wageningen, The Netherlands, 5-9 May 1997.

17. Patrick, C.; Segwage, B.; Aganga, A. A review of donkey uses in Botswana over a ten-year period. In Proceedings of the Animal Traction Network for Eastern and Southern Africa (ATNESA) Empowering Farmers with Animal Traction, Mpumalanga, South Africa, 20-24 September 1999.

18. Starkey, P.; Starkey, M. Regional and world trends in donkey populations. In Donkeys, People, and Development. A Resource Book of the Animal Traction Network for Eastern and Southern Africa (ATNESA); Starkey, P., Fielding, D., Eds.; ACP-EU Technical Centre for Agricultural and Rural Cooperation (CTA): Wageningen, The Netherlands, 2000; 247p, ISBN 92-9081-219-2. Available online: http://www.atnesa.org (accessed on 10 September 2018).

19. Mrema, M. Economic and Gender Issues of Donkey Use in Kweneng and Kgatleng Districts, Botswana. Donkeys, People and Development. A Resource Book of the Animal Traction Network for Eastern and Southern Africa (ATNESA); Starkey, P., Fielding, D., Eds.; ACP-EU Technical Centre for Agricultural and Rural Cooperation (CTA): Wageningen, The Netherlands, 2004; 168p. Available online: http://www.atnesa.orgAvailable online: http://www.atnesa.org/donkeys/donkeys-mrema-gender-BW.pdf (accessed on 10 September 2018).

20. Swai, E.S.; Bwanga, S.J.R. Donkey keeping in northern Tanzania: Socio-economic roles and reported husbandry and health constraints. Livest. Res. Rural Dev. 2008, 20,1-97.

21. Hassan, M.R.; Steenstra, F.A.; Udo, H.M.J. Benefits of donkeys in rural and urban areas in northwest Nigeria. Afr. J. Agric. Res. 2013, 8, 6202-6212.

22. Geiger, M.; Hovorka, A.J. Using physical and emotional parameters to assess donkey welfare in Botswana. Vet. Rec. Open 2015, 2. [CrossRef] [PubMed]

23. Knowles, G.; Gallagher, I. Decimation of the donkeys: How 4 Million animals are slaughtered every year to make Chinese "miracle" youth serum. Daily Mail Online. 30 November 2016. Available online: http://www.dailymail.co.uk/news/article-3930644/Decimation-donkeys-4MILLIONanimals-slaughtered-year-make-Chinese-miracle-youth-serum.html (accessed on 4 September 2018).

24. Monks, K. China banned from buying donkeys. CNN. 30 November 2016. Available online: http: //edition.cnn.com/2016/09/29/africa/china-african-donkeys (accessed on 4 September 2018).

25. Baker, M. The donkey skin market: Threat for donkey world population and rural African communities. International Organisation for Animal Protection (OIPA). 28 February 2017. Available online: https://www.oipa. org/international/donkeyskin/\#prettyPhoto (accessed on 4 September 2018).

26. Statistics Botswana. 2007 and 2008 Annual Agricultural Survey Report; Government of Botswana: Gaborone, Botswana, 2012.

27. The Donkey Sanctuary. Under the Skin: Update on the Global Crisis for Donkeys and the People Who Depend on Them. 2019. Available online: https://www.thedonkeysanctuary.org.uk/sites/uk/files/2019-12/ under-the-skin-report-english-revised-2019.pdf (accessed on 12 November 2019).

28. Baker, M. The donkey skin trade is threatening livelihoods and communities-we need to act now. The Guardian. 29 January 2017. Available online: https://www.theguardian.com/global-development-professionalsnetwork/2017/jan/29/donkey-skin-trade-threatening-communities-tanzania (accessed on 7 September 2018).

29. Chu, N.L.; Wu, Z.K.; Zhang, X.H.; Fang, S.P.; Wang, W.J.; Cheng, Y.L. Molecular mechanism of Yisui Shengxue Granule, a complex Chinese medicine, on thalassemia patients suffering from hemolysis and anemia of erythrocytes. Evid. -Based Complement. Altern. Med. 2014. [CrossRef] [PubMed]

30. Yang, F.; Song, J.; Liang, M.; Ma, F.; Mao, X.; Ma, C.W.; Zhang, W.; Huang, Z. Overview of Beverages with Anti-Aging Functions in Chinese Market. Rejuvenation Res. 2014, 17, 1-4. [CrossRef] [PubMed]

31. Chen, Y.; Zhang, G.; Chen, X.; Jiang, X.; Bie, F.; Yuan, N.; Wang, Y.; Hao, X.; Ma, M. Jianpi Bushen, a Traditional Chinese Medicine Therapy, Combined with Chemotherapy for Gastric Cancer Treatment: A Meta-Analysis of Randomized Controlled Trials. Evid. -Based Complement. Altern. Med. 2018. [CrossRef] [PubMed]

32. Wang, D.; Liu, M.; Cao, J.; Cheng, Y.; Zhuo, C.; Xu, H.; Tian, S.; Zhang, Y.; Zhang, J.; Wang, F. Effect of Colla corii asini (Ejiao) on D-Galactose Induced Aging Mice. Biol. Pharm. Bull. 2012, 35, 2128-2132. [CrossRef] [PubMed]

33. Nkala, O. Botswana eyes donkey trade with Asia. Oxpeckers. June 2018. Available online: https://oxpeckers. org/2018/06/botswana-eyes-donkey-trade-with-asia/ (accessed on 12 November 2019). 
34. The Economist. Africans want to sell donkey skins. Western charities want to stop them-Saving asses. The Economist. 8 March 2018. Available online: https://www.economist.com/middle-east-and-africa/2018/03/08/ africans-want-to-sell-donkey-skins.-western-charities-want-to-stop-them (accessed on 12 November 2019).

35. Gardner, H. China has a donkey shortage-And why that matters. USA TODAY. 17 July 2017. Available online: https://www.usatoday.com/story/news/world/2017/07/17/china-donkey-shortage/456034001/ (accessed on 10 September 2018).

36. Sadeque, S. China in Africa: Donkeys Are Safe from Slaughter Export, for Now. 20 February 2018. Available online: https://qz.com/africa/1211541/China-in-africa-donkeys-are-safe-from-slaughter-export-for-now/ (accessed on 4 September 2018).

37. The Economist. Donkey skins are the new ivory. The Economist. 30 March 2018. Available online: https: //www.economist.com/graphic-detail/2018/03/30/donkey-skins-are-the-new-ivory (accessed on 9 April 2018).

38. Monks, K. Why is China buying up the global supply of donkeys? CNN. 29 September 2016. Available online: https://edition.cnn.com/2016/09/29/africa/chinaafricandonkeys/index.html (accessed on 12 November 2019).

39. Cole, M.A. Trade, the pollution haven hypothesis and the environmental Kuznets curve: Examining the linkages. Ecol. Econ. 2004, 48, 71-81. [CrossRef]

40. Zhu, C.; Taylor, R.; Feng, G. China's Wood Market, Trade and the Environment; Science Press Inc.: Monmouth Junction, NJ, USA, 2004.

41. Liu, J. Forest Sustainability in China and Implications for a Telecoupled World. Asia Pac. Policy Stud. 2013, 1, 230-250. [CrossRef]

(C) 2020 by the authors. Licensee MDPI, Basel, Switzerland. This article is an open access article distributed under the terms and conditions of the Creative Commons Attribution (CC BY) license (http://creativecommons.org/licenses/by/4.0/). 